\title{
ECHDC3 wt Allele
}

National Cancer Institute

\section{Source}

National Cancer Institute. ECHDC3 wt Allele. NCI Thesaurus. Code C162360.

Human ECHDC3 wild-type allele is located in the vicinity of 10p14 and is approximately 22 $\mathrm{kb}$ in length. This allele, which encodes enoyl-CoA hydratase domain-containing protein 3, mitochondrial, may be involved in fatty acid biosynthesis. 